\title{
Consumption of mate tea (Ilex paraguariensis) decreases the oxidation of unsaturated fatty acids in mouse liver
}

\author{
Fernanda Martins ${ }^{1}$, Amanda Janaína Suzan ${ }^{1}$, Suzete Maria Cerutti ${ }^{2}$, Demétrius Paiva Arçari ${ }^{3}$, \\ Marcelo Lima Ribeiro ${ }^{3}$, Débora Helena Markowicz Bastos ${ }^{4}$ and Patrícia de Oliveira Carvalho ${ }^{1 *}$ \\ ${ }^{1}$ Laboratório Multidisciplinar de Pesquisa, Universidade São Francisco, Av. São Francisco de Assis 218, Bragança Paulista, \\ SP, Brazil \\ ${ }^{2}$ Laboratório de Plasticidade Neural e Fitoterápicos, Universidade São Francisco, Av. São Francisco de Assis 218, Bragança \\ Paulista, SP, Brazil \\ ${ }^{3}$ Unidade Integrada de Farmacologia e Gastroenterologia, Universidade São Francisco, Av. São Francisco de Assis 218, Bragança \\ Paulista, SP, Brazil \\ ${ }^{4}$ Departamento de Nutrição, Faculdade de Saúde Pública, Av. Dr. Arnaldo 715, Universidade de São Paulo, SP, Brazil \\ (Received 18 December 2007 - Revised 21 April 2008 - Accepted 23 May 2008 - First published online 19 August 2008)
}

\begin{abstract}
Mate (Ilex paraguariensis) is rich in polyphenolic compounds, which are thought to contribute to the health benefits of tea. Mate tea was administered orally to mice at a dose of $0.5,1.0$ or $2.0 \mathrm{~g} / \mathrm{kg}$ for $60 \mathrm{~d}$, and changes both in serum lipid concentration and fatty acid composition of liver and kidney were examined. The effects of mate tea on serum and tissue lipid peroxidation were assessed by the evaluation of thiobarbituric acidreactive substances (TBARS). In tea-consuming mice, both MUFA $(18: 1 n-9)$ and PUFA $(18: 2 n-6$ and $20: 4 n-6)$ were increased $(P<0 \cdot 05)$ in the liver lipid (approximately 90 and $60 \%$, respectively), whereas only MUFA (approximately 20\%) were increased in the kidney lipid. The most altered PUFA class was $n$-6 PUFA, which increased by approximately $60-75 \%(P<0.05)$. This difference in the fatty acid profile in the liver is reflected in the increased PUFA:SFA ratio. Consistent with these results, mice fed with mate tea had much lower TBARS in the liver. No differences $(P>0.05)$ were found in the levels of serum cholesterol, HDL-cholesterol and TAG under the conditions of the present study. These results suggest that treatment with mate tea was able to protect unsaturated fatty acids from oxidation and may have selective protective effects within the body, especially on the liver.
\end{abstract}

Ilex paraguariensis: Mate tea: Unsaturated fatty acids: Liver peroxidation

Mate (Ilex paraguariensis St Hilaire) is a plant originally from the subtropical region of South America, and present in the South of Brazil, North of Argentina, Paraguay and Uruguay. Mate beverages have been widely consumed for hundreds of years as infusions popularly known as chimarrão, tererê (both from green dried mate leaves) and mate tea (roasted mate leaves). Mate beverages are rich in polyphenolic compounds, which are mainly caffeoyl derivates such as dicaffeoylquinic and chlorogenic acids, saponins and purine alkaloids ${ }^{(1,2)}$.

Recently published research has scientifically proven the effects of $I$. paraguariensis, which include chemopreventive activities (preventing cellular damage that may cause chronic diseases $)^{(3,4)}$, choleretic effects and intestinal propulsion ${ }^{(5)}$, vasodilatation effects ${ }^{(6,7)}$, inhibition of glycation (non-enzymic reaction between blood sugar, proteins and lipids, forming products that accumulate and provide stable sites for catalysing the formation of free radicals) ${ }^{(8)}$ and atherosclerosis ${ }^{(9)}$.

Although a number of mechanisms have been proposed for the beneficial effects of mate, the radical scavenging and antioxidant properties of tea polyphenols are frequently cited as important contributors. In fact, mate extracts have been shown to inhibit LDL oxidation in vitro, and reported for the first time by Gugliucci \& Stahl ${ }^{(10)}$ to possess free radical-scavenging ability ${ }^{(11)}$ and to protect human plasma against ex vivo lipid peroxidation ${ }^{(12)}$. Much of the evidence supporting an antioxidant function for $I$. paraguariensis extracts is derived from assays assessing their antioxidant activity in vitro ${ }^{(13-16)}$. However, evidence that mate extracts act directly or indirectly as antioxidants in vivo is more limited. A protecting effect against DNA damage after $\mathrm{H}_{2} \mathrm{O}_{2}$ challenge has been shown in liver cells ${ }^{(17)}$ and an anti-inflammatory effect in lungs damaged by cigarette smoke exposure $^{(18)}$ has been observed in experiments in mice. Mosimann et al. ${ }^{(9)}$ reported that $I$. paraguariensis extract can inhibit the progression of atherosclerosis in cholesterol-fed rabbits, although it did not decrease the serum cholesterol and antioxidant enzymes. On the other hand, Stein et al. ${ }^{(7)}$ reported that oral administration of $I$. paraguariensis in

Abbreviation: TBARS, thiobarbituric acid-reactive substances.

* Corresponding author: Dr Patrícia de Oliveira Carvalho, fax +55 11 40341825, email patcarvalho@saofrancisco.edu.br 
hypercholesterolaemic rats resulted in a significant reduction in serum levels of cholesterol (30\% reduction) and TAG (60.4\% reduction).

However, to our knowledge, no study has been conducted to explore the antioxidant activity of mate tea vis-à-vis unsaturated fatty acid oxidation in the liver and kidney of mice, critical organs in the regulation and synthesis of lipids. It is known that the high vulnerability of the kidney to lipid peroxidation has been partly attributed to its high content of long-chainPUFA, such as arachidonic and $\mathrm{DHA}^{(19)}$ and the occurrence of potentially neoplastic hepatocyte lesions is associated with changes in the PUFA profile and the lipid peroxidative status ${ }^{(15)}$.

Taking all these points into consideration, the aim of the present study was to determine the effect of consumption of mate tea on fatty acid profiles and peroxidative status in mice serum, liver and kidney. In addition serum cholesterol, lipoproteins and TAG concentrations were determined.

\section{Materials and methods}

\section{Mate preparation and reagents}

The roasted I. paraguariensis mate tea beverage was prepared by dissolving lyophilised instant mate tea (Leão Jr, CuritibaPR, Brazil) in water using a homogeniser and was prepared fresh each day. Butylated hydroxytoluene, TCA, thiobarbituric acid, 1,1,3,3-tetramethoxypropane, 2-amino-2-hydroxymethylpropane-1,3-diol-HCl, EDTA, $\mathrm{KCl}$, xylazine-ketamine and fatty acid standard were purchased from Sigma Chemicals (St Louis, MO, USA). $\mathrm{BF}_{3}-$ methanol and chloroform were purchased from Merck-Brazil (São Paulo, Brazil).

\section{Animals and diets}

Forty male Swiss mice (weight $10-15 \mathrm{~g}$ ) free of specific pathogens were obtained from CEMIB (Centro Multidisciplinar de Bioterismo, UNICAMP, Campinas, Brazil) and were kept in groups of five animals per cage. Throughout the experiment, animals were housed in a room under a $12 \mathrm{~h}$ dark $-12 \mathrm{~h}$ light cycle (lights turned on at 06.00 hours) with controlled temperature $\left(22^{\circ} \mathrm{C} \pm 2^{\circ} \mathrm{C}\right)$ and relative humidity $(53 \pm 2 \%)$, with free access to food and water. The mice were randomly assigned to four groups, according to the intervention and dose used. The animals were treated for 60 consecutive days and received three different doses of mate tea: $0.5 \mathrm{~g} / \mathrm{kg}$ ( $n$ 10), $1.0 \mathrm{~g} / \mathrm{kg}(n 10)$ or $2.0 \mathrm{~g} / \mathrm{kg}(n 10)$. These doses are equal to those found in $0.75,1.5$ and 3 litres mate tea/d, respectively $^{(17)}$. Other animals were used as a control group and received water $(n 10)$. The aqueous mate tea and the pure water were administered by intragastric gavage. After the intervention, mice were deeply anaesthetised (xylazine-ketamine, 1:1) and blood samples were collected by heart puncture. The serum was obtained by centrifugation of blood at $800 \mathrm{~g}$ for $10 \mathrm{~min}$ and immediately the total cholesterol, TAG and HDLcholesterol concentrations were determined using the CobasMira System (Roche Diagnostics, Indianapolis, IN, USA). LDL-cholesterol was calculated from the formula: LDL-cholesterol $(\mathrm{mg} / \mathrm{l})=$ total cholesterol $-\mathrm{TAG} / 5-$ HDL-cholesterol.

The animals were killed by a transcardiac perfusion with $70 \mathrm{ml}$ isotonic saline solution $\left(4^{\circ} \mathrm{C}\right)$ over a period of $6 \mathrm{~min}$. The livers and kidneys were removed, weighed and rinsed with ice-cold isotonic saline solution. Portions of these tissues were removed, pulverised in liquid $\mathrm{N}_{2}$, and stored at $-80^{\circ} \mathrm{C}$ using a Dura Dry Freezer and later used for the determination of hepatic and kidney fatty acids and measurement of thiobarbituric acid-reactive substances (TBARS) content.

The procedures used for the manipulation of animals were in agreement with the Ethical Principles in Animal Research, adopted by the Brazilian College for Animal Experimentation (COBEA), according to the APA Guidelines for Ethical Conduct in the Care and Use of Animals.

\section{Thiobarbituric acid-reactive substances measurement}

The contents of TBARS in serum, kidney and liver homogenates were determined ${ }^{(20)}$. Briefly, $250 \mu$ l of sample were mixed with $25 \mu \mathrm{l} 4 \%$ butylated hydroxytoluene in methanol, $1 \mathrm{ml} 12 \%$ TCA, $1 \mathrm{ml} 0.73 \%$ thiobarbituric acid and $750 \mu \mathrm{l}$ 0.1 M-2-amino-2-hydroxymethyl-propane-1,3-diol-HCl buffer containing $0 \cdot 1 \mathrm{~mm}$-EDTA ( $\mathrm{pH} 7 \cdot 4$ ). After $60 \mathrm{~min}$ incubation at $100^{\circ} \mathrm{C}$, the samples were cooled on ice, added to $1.5 \mathrm{ml}$ $n$-butanol, vortex mixed for $30 \mathrm{~s}$ and centrifuged at $1000 \mathrm{~g}$ for $10 \mathrm{~min}$. The absorbance of the supernatant fraction was measured at $532 \mathrm{~nm}$. The method was standardised with 1,1,3,3-tetramethoxypropane (malondialdehyde bis dimethyl acetyl), used as a standard. The concentration of lipid peroxidation products was expressed in nmol malonaldehyde equivalents per mg protein as previously determined ${ }^{(21)}$.

\section{Fatty acid composition}

For total lipid extraction, frozen tissue samples were homogenised in chloroform and methanol $(2: 1, \mathrm{v} / \mathrm{v})$, followed by the addition of an aqueous solution of $\mathrm{KCl}^{(22)}$. The chloroform layer was dried under $\mathrm{N}_{2}$ and the total extract was converted into methyl esters of fatty acids using $\mathrm{BF}_{3}-$ methanol, according to the method suggested by the American Oil Chemists' Society $^{(23)}$. The methyl esters were diluted in hexane and analysed by GC using a CHROMPACK ${ }^{\circledR}$ chromatographer (model CP 9001; Chrom Tech, Inc., Apple Valley, MN, USA) with a flame ionisation detector and a CP-Sil 88 capillary column (Chrompak, WCOT Fused Silica $59 \mathrm{~m} \times 0.25 \mathrm{~mm}$ ). The detector temperature was $280^{\circ} \mathrm{C}$ and the temperature of the injector was $250^{\circ} \mathrm{C}$. The initial temperature was $180^{\circ} \mathrm{C}$ for $2 \mathrm{~min}$, programmed to increase by $10^{\circ} \mathrm{C}$ per min up to $210^{\circ} \mathrm{C}$, and held for $30 \mathrm{~min}$. The carrier gas used was $\mathrm{H}_{2}$ at a flow rate of $2.0 \mathrm{ml} / \mathrm{min}$. The identification of the fatty acids was made by comparing the retention times of the sample components with authentic standards (Sigma) of fatty acid esters injected under the same conditions. Fatty acid composition, as a percentage of total acid weight, was calculated using area counts of the chromatogram.

\section{Statistical analysis}

All data are expressed as mean values with their standard errors of five replicates. The composition of fatty acids from mice liver was analysed by one-way ANOVA and the comparison of groups was performed using the Dunnett's multiple comparison test. Statistical tests were performed using BioEstat 1.0 (BioEstat, Fortaleza, Brazil) and an associated probability ( $P$ value) of less than 0.05 was considered significant. 


\section{Results}

The composition of fatty acids in liver and kidney lipids for the treated groups and control group is shown in Table 1. Significant increases $(P>0.05)$ in the concentrations of MUFA and PUFA were found in the liver homogenates of the treated groups, with an increase in relative concentration of oleic acid $(18: 1 n-9 ; 63 \%$ for the group treated with $0.5 \mathrm{~g} / \mathrm{kg}$ and approximately $95 \%$ for the groups treated with 1.0 and $2.0 \mathrm{~g} / \mathrm{kg})$, linoleic acid $(18: 2 n-6 ; 90 \%$ for the group treated with $0.5 \mathrm{~g} / \mathrm{kg}$ and $114 \%$ for the groups treated with 1.0 and $2.0 \mathrm{~g} / \mathrm{kg}$ ) and arachidonic acid $(20: 4 n-6$; approximately $40 \%$ for the groups treated with the three doses) (Table 1). The most altered PUFA class was $n$-6 PUFA, which increased by approximately $60-75 \%(P<0.05)$, compared with the control group. No significant changes were observed in $n-3$ PUFA in any of the groups. Conversely, the proportion of SFA was significantly decreased in the treated groups, with a significant reduction in the relative abundance of palmitic acid (16:0; approximately $50 \%$ ). Consequently, the total PUFA:SFA ratio was increased by approximately $100-180 \%$ in the liver of tea-consuming animals.

On the other hand, the fatty acid profiles of the kidney homogenates show that only MUFA was increased in the tea-consuming animals at the dose of $2 \cdot 0 \mathrm{~g} / \mathrm{kg}$. The other treated groups $(0.5$ and $1.0 \mathrm{~g} / \mathrm{kg})$ showed a tendency towards elevation of the concentration of MUFA $(18: 1 n-9)$ in the renal lipids, but no significant $(P>0.05)$ differences were found between the different identified fatty acids, when compared with the control animals.

Mate tea consumption significantly decreased the levels of TBARS (malonaldehyde equivalents) in the liver homogenates
(Fig. 1). Malonaldehyde equivalents in the water-consuming animals were $50-60 \%$ greater than in the tea-consuming animals, implying protection by the tea against oxidative stress in this tissue. These results differed from those obtained with kidney homogenates, in which malonaldehyde equivalents were unaffected by tea consumption.

The concentrations of serum TBARS and lipids are shown in Table 2. Serum TBARS were lower in the mice administered with 1.0 and $2.0 \mathrm{~g}$ mate tea $/ \mathrm{kg}$ than in the control mice $(P<0.05)$. The serum total cholesterol, HDL-cholesterol and TAG levels in the three treated groups did not differ from the control group. The tea-consuming animals, at a dose of $2 \cdot 0 \mathrm{~g} / \mathrm{kg}$, showed a slightly lower level of serum total cholesterol (approximately 10\%), but this was not statistically significant. Mate tea consumption had no effect on average body mass in all groups throughout the study.

\section{Discussion}

The results demonstrate that the mixture of antioxidants present in mate tea is able to protect unsaturated fatty acids in the liver from oxidation, as suggested by the increase in PUFA $n-6$ content shown here. The lower content of PUFA $n-6$ in the liver of animals treated with water shows that they were more susceptible to free radical attack and subsequent peroxidation in this tissue, which may be confirmed by the difference in the values of the TBARS between the control and treated groups. The TBARS level is one of the most popular markers of lipid peroxidation and, in the present study, mate tea consumption led to a significant decrease in the serum and liver homogenate TBARS levels (Table 2 and Fig. 1). The levels of lipid peroxidation products in liver

Table 1. Effect of mate tea (Ilex paraguariensis) on the fatty acid composition of liver and kidney lipids of mice

(Mean values with their standard errors; $n$ 5)

\begin{tabular}{|c|c|c|c|c|c|c|c|c|c|c|c|c|c|c|c|c|}
\hline \multirow[b]{4}{*}{ Fatty acids } & \multicolumn{8}{|c|}{ Liver } & \multicolumn{8}{|c|}{ Kidney } \\
\hline & \multicolumn{6}{|c|}{ Treated groups } & & & \multicolumn{6}{|c|}{ Treated groups } & \multirow{2}{*}{\multicolumn{2}{|c|}{$\begin{array}{l}\text { Control } \\
\text { group }\end{array}$}} \\
\hline & \multicolumn{2}{|c|}{$0.5 \mathrm{~g} / \mathrm{kg}$} & \multicolumn{2}{|c|}{$1.0 \mathrm{~g} / \mathrm{kg}$} & \multicolumn{2}{|c|}{$2.0 \mathrm{~g} / \mathrm{kg}$} & \multicolumn{2}{|c|}{$\begin{array}{l}\text { Control } \\
\text { group }\end{array}$} & \multicolumn{2}{|c|}{$0.5 \mathrm{~g} / \mathrm{kg}$} & \multicolumn{2}{|c|}{$1.0 \mathrm{~g} / \mathrm{kg}$} & \multicolumn{2}{|c|}{$2.0 \mathrm{~g} / \mathrm{kg}$} & & \\
\hline & Mean & SEM & Mean & SEM & Mean & SEM & Mean & SEM & Mean & SEM & Mean & SEM & Mean & SEM & Mean & SEM \\
\hline \multicolumn{17}{|l|}{ SFA } \\
\hline $16: 0$ & $31.33^{*}$ & 1.53 & $23.33^{*}$ & 1.53 & $25 \cdot 00^{*}$ & 1.05 & 42.05 & 3.02 & $24 \cdot 10$ & 2.35 & $22 \cdot 30$ & 2.05 & 23.42 & 1.97 & $23 \cdot 17$ & 1.65 \\
\hline $18: 0$ & $9 \cdot 37$ & 1.50 & 8.97 & 1.50 & 8.02 & 1.51 & $12 \cdot 37$ & $2 \cdot 80$ & 5.45 & 1.44 & 6.32 & 1.54 & $5 \cdot 86$ & 0.98 & $6 \cdot 22$ & 0.56 \\
\hline $20: 0$ & 1.50 & 0.63 & $1 \cdot 21$ & 0.93 & 1.49 & 1.23 & 2.02 & 1.04 & $1 \cdot 88$ & 1.45 & 1.54 & 1.21 & 1.08 & 1.09 & 1.57 & 1.82 \\
\hline$\Sigma S F A$ & $42 \cdot 20^{\star}$ & 2.56 & $33 \cdot 51^{*}$ & $2 \cdot 32$ & $34.51^{*}$ & 2.65 & 56.44 & 2.43 & 31.43 & 2.75 & $30 \cdot 16$ & $2 \cdot 82$ & $30 \cdot 36$ & $2 \cdot 13$ & 30.96 & 2.35 \\
\hline \multicolumn{17}{|l|}{ MUFA } \\
\hline $16: 1 n-7$ & $1 \cdot 86$ & 0.82 & $1 \cdot 16$ & 0.67 & 1.09 & 0.86 & 1.89 & 0.82 & 4.02 & 1.84 & $6 \cdot 33$ & 1.47 & 7.09 & 1.89 & 5.94 & 1.72 \\
\hline $18: 1 n-9$ & $19 \cdot 93^{\star}$ & $2 \cdot 60$ & $23 \cdot 67^{*}$ & 3.51 & $23 \cdot 33^{*}$ & 1.15 & $12 \cdot 20$ & 3.02 & $30 \cdot 37$ & 2.50 & 28.53 & $2 \cdot 16$ & $31 \cdot 17$ & $2 \cdot 80$ & $25 \cdot 66$ & 2.08 \\
\hline ¿MUFA & $21 \cdot 79^{\star}$ & 2.32 & $24 \cdot 83^{*}$ & 2.76 & $24.42^{*}$ & 1.30 & 14.09 & $2 \cdot 78$ & $34 \cdot 39$ & 2.97 & $34 \cdot 86$ & $2 \cdot 13$ & $38 \cdot 26^{*}$ & 2.54 & 31.60 & $2 \cdot 32$ \\
\hline \multicolumn{17}{|l|}{ PUFA } \\
\hline $18: 2 n-6$ & $17 \cdot 50^{\star}$ & 2.29 & $19 \cdot 73^{*}$ & $2 \cdot 10$ & $19 \cdot 70^{*}$ & 2.43 & 9.22 & $1 \cdot 18$ & $20 \cdot 13$ & 1.15 & $21 \cdot 31$ & 1.87 & $20 \cdot 42$ & 1.21 & 20.03 & $2 \cdot 18$ \\
\hline $18: 3 n-3$ & 1.54 & 0.62 & 1.82 & 0.49 & 1.46 & 0.55 & 1.72 & 0.63 & 1.82 & 0.84 & 1.94 & 0.77 & 1.79 & 0.44 & 1.91 & 0.61 \\
\hline $20: 4 n-6$ & $8.07^{\star}$ & 0.11 & $8.57^{\star}$ & 0.47 & $8 \cdot 53^{*}$ & 0.45 & 5.98 & 0.97 & 4.50 & 0.98 & 5.03 & 1.70 & 4.09 & 1.98 & 3.50 & 1.08 \\
\hline $20: 5 n-3$ & \multirow{2}{*}{\multicolumn{2}{|c|}{1.86 nd }} & 1.09 & 0.82 & 1.22 & 1.01 & 1.50 & 0.70 & 0.77 & 0.34 & \multirow{2}{*}{\multicolumn{2}{|c|}{$\begin{array}{l}0.58 \\
\text { nd }\end{array}$}} & 0.69 & 0.39 & \multirow{2}{*}{\multicolumn{2}{|c|}{0.88 nd 0.13}} \\
\hline $22: 6 n-3$ & & & 0.77 & 0.62 & \multicolumn{2}{|c|}{ nd } & 0.93 & 0.44 & \multicolumn{2}{|c|}{ nd } & & & $n$ & & & \\
\hline ¿PUFA & $28.97^{*}$ & $2 \cdot 12$ & $31.98^{*}$ & $2 \cdot 20$ & $30.91^{*}$ & 2.45 & $19 \cdot 35$ & 1.78 & $27 \cdot 22$ & 1.89 & $28 \cdot 86$ & $2 \cdot 56$ & 26.99 & $2 \cdot 86$ & $26 \cdot 32$ & 3.34 \\
\hline PUFA:SFA & \multicolumn{2}{|c|}{0.68} & \multicolumn{2}{|c|}{0.95} & \multicolumn{2}{|c|}{0.89} & \multicolumn{2}{|c|}{0.34} & \multicolumn{2}{|c|}{0.87} & \multicolumn{2}{|c|}{0.95} & \multicolumn{2}{|c|}{0.89} & \multicolumn{2}{|c|}{0.85} \\
\hline
\end{tabular}

nd, Not detected.

* Mean value was significantly different from that of the respective control group $(P<0.05$; Dunnett's multiple comparison test). 


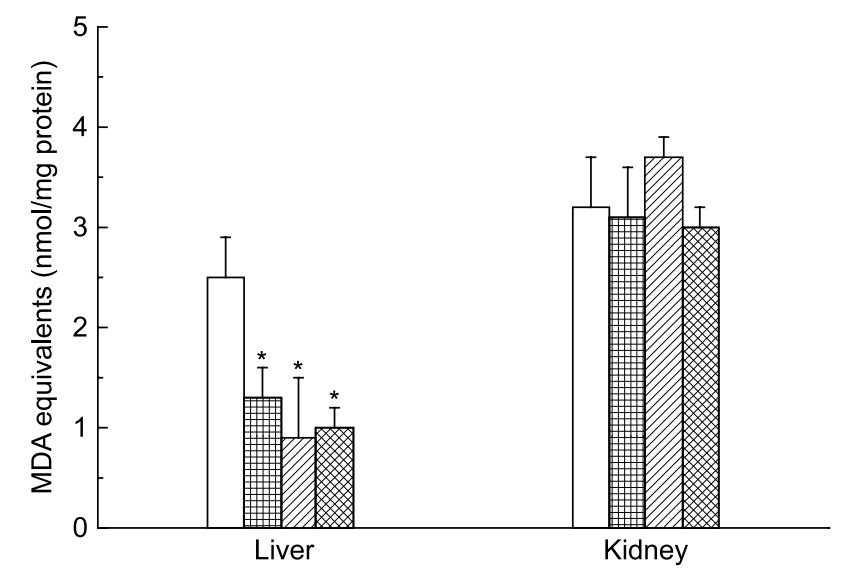

Fig. 1. Effect of mate tea (Ilex paraguariensis) on levels of lipid peroxidation products in the liver and kidney of mice. ( $\square$ ), Water (control); (田), mate tea at $0.5 \mathrm{~g} / \mathrm{kg} ;(\Xi)$, mate tea at $1.0 \mathrm{~g} / \mathrm{kg} ;(\otimes)$, mate tea at $2.0 \mathrm{~g} / \mathrm{kg}$. Lipid peroxidation products were measured as malonaldehyde (MDA) equivalents. Values are means $(n 5)$, with standard deviations represented by vertical bars. * Mean value was significantly different from that of the control group $(P<0.05)$.

and kidney homogenates were similar to those reported in other studies using rats ${ }^{(14,24)}$ and rabbits ${ }^{(9)}$.

Although no studies of the effect of mate tea on the composition of fatty acids in murine tissues have been reported, similar results were described by others studying the effect of polyphenol-rich extracts ${ }^{(25,26)}$. Previous reports show unchanged long-chain-PUFA contents of kidney and erythrocytes found in red wine-consuming rats, in contrast with the diminished levels shown by an ethanol-consuming group; this was interpreted as the result of the cytoprotective effect exerted by red wine polyphenols ${ }^{(25)}$. This hypothesis is supported by the demonstration that the major polyphenols of red wine inhibit the synthesis of eicosanoids through mechanisms that include the inhibition of phospholipase $\mathrm{A}_{2}$ and cyclo-oxygenase $^{(27)}$. The differences in long-chain-PUFA levels and the extent of lipid peroxidation in pre-neoplastic lesions have been attributed to an abnormal essential fatty acid metabolism involving $\Delta$-6 desaturase ${ }^{(28)}$. These changes are known to affect the membrane structure and fluidity, the activity of membrane enzymes and the affinity of growth factor receptors. It was found that wine flavonoids, such as quercetin, may exert a protective effect against cytotoxicity of reactive oxygen species, due to their membrane affinity ${ }^{(29)}$.

According to Bixby et al. ${ }^{(30)}$, mate extract polyphenol levels are higher than those of green tea and similar to those of red wines. Other authors have reported that the antioxidant activity of I. paraguariensis extract is two times higher compared with red wine ${ }^{(31)}$. Data from the literature show that, compared with other varieties of Ilex, I. paraguariensis exhibited the highest antioxidant activity, inhibiting a chemically initiated oxidation of synthetic membranes (liposomes), as measured by TBARS production ${ }^{(13)}$.

Phenolic compounds present in roasted mate are mainly chlorogenic acids (mono- and dicaffeoylquinic acids) and hydroxycinnamic acids (caffeic acid, quinic acid). Earlier studies have shown that rutin, a flavonoid present in the green yerba-mate leaves, is lost after the roasting process ${ }^{(2)}$. Although there is little knowledge about the bioavailability of compounds of mate, the observed protection may be related to the presence of polyphenolic compounds; chlorogenic acid (the main phenolic compound in mate leaves) is a potent antioxidant compound and may act as a hydrogen or electron donor, as well as a transition metal ion chelator ${ }^{(32)}$.

Under the conditions of the present study, non-significant $(P>0.05)$ differences were found in the serum total cholesterol, HDL-cholesterol and TAG levels. These results seem to be in agreement with data from Mosimann et al. ${ }^{(9)}$, who repoerted non-significant difference in levels of total cholesterol, HDLcholesterol and TAG in the serum of cholesterol-fed rabbits after consumption of mate extract for 2 months. On the other hand, another study has documented that in chlorogenic acidtreated rats, plasma cholesterol and TAG concentrations significantly decreased (44 and $58 \%$, respectively). In this study, the chlorogenic acid was infused intravenously $\left(5 \mathrm{mg} / \mathrm{kg}\right.$ body weight per d) for 3 weeks $^{(33)}$. Stein et al. ${ }^{(7)}$ reported that rats fed with the hypercholesterolaemic diet for $30 \mathrm{~d}$ and treated for the last $15 \mathrm{~d}$ with I. paraguariensis $(500 \mathrm{mg} / \mathrm{kg})$ had significantly reduced levels of serum cholesterol (30\% reduction) and TAG (60.4\% reduction) compared with the hypercholesterolaemic diet alone.

Our data suggest that there is less oxidative stress to lipids in the liver of animals that consume mate tea. This evidence

Table 2. Effect of mate tea (Ilex paraguariensis) on lipid and thiobarbituric acid-reactive substances (TBARS) concentrations in the serum of mice

(Mean values with their standard errors; $n 5$ )

\begin{tabular}{|c|c|c|c|c|c|c|c|c|}
\hline & \multicolumn{6}{|c|}{ Treated groups } & & \\
\hline & \multicolumn{2}{|c|}{$0.5 \mathrm{~g} / \mathrm{kg}$} & \multicolumn{2}{|c|}{$1.0 \mathrm{~g} / \mathrm{kg}$} & \multicolumn{2}{|c|}{$2.0 \mathrm{~g} / \mathrm{kg}$} & & \\
\hline & Mean & SEM & Mean & SEM & Mean & SEM & \multicolumn{2}{|c|}{ Control group } \\
\hline \multicolumn{9}{|l|}{ Serum lipids (mg/l) } \\
\hline Total cholesterol & 1287 & 34 & 1293 & 31 & 1209 & 59 & 1340 & 46 \\
\hline HDL-cholesterol & 504 & 15 & 528 & 18 & 494 & 23 & 538 & 17 \\
\hline LDL-cholesterol $†$ & 479 & - & 472 & - & 413 & - & 487 & - \\
\hline TAG & 1506 & 36 & 1467 & 17 & 1510 & 13 & 1574 & 38 \\
\hline TBARS (nmol/ml) & 2.49 & 0.15 & $1.32^{*}$ & 0.08 & $1.44^{*}$ & 0.10 & 2.87 & $0 \cdot 12$ \\
\hline Weight (g) & $20 \cdot 5$ & 1.4 & $19 \cdot 7$ & $2 \cdot 4$ & 21.5 & $1 \cdot 6$ & $20 \cdot 7$ & $2 \cdot 0$ \\
\hline
\end{tabular}

* Mean value was significantly different from that of the respective control group $(P<0.05$; Dunnett's multiple comparison test)

†LDL-cholesterol was calculated from the formula: LDL-cholesterol $(\mathrm{mg} / \mathrm{l})=$ total cholesterol $-\mathrm{TAG} / 5$ - HDL-cholesterol. 
supports the contention that the ingestion of mate tea might be an effective and economic way to provide an important amount of compounds that increase the antioxidant defensive system of an organism and should be coupled with antioxidant therapy to minimise the peroxidative damage of liver lipids. Our work should pave the way for further studies using the same target.

\section{Acknowledgements}

We thank Financiadora de Estudos e Projetos (FINEP) and Leão Junior S/A for financial support.

The authors declare no conflicts of interest.

The article was conceptualised by all authors; F. M. and A. J. S. carried out the laboratory analysis; S. M. C. and D. P. A. conducted the experimental work with the animals; D. H. M. B., M. L. R. and P. O. C. participated in the design of the study and coordination; F. M. and P. O. C. drafted the manuscript. All authors read and approved the final manuscript.

\section{References}

1. Bastos DHM, De Oliveira DM, Matsumoto RLT, Carvalho PO \& Ribeiro ML (2007) Yerba mate: pharmacological properties, research and biotechnology. Med Aromat Plant Sci Biotechnol 1, 37-46.

2. Bastos DHM, Saldanha LS, Catharino RR, Sawaya ACHF, Cunha IBC, Carvalho PO \& Eberlin MN (2007) Phenolic antioxidants identified by ESI-MS from Yerba mate (Ilex paraguariensis) and green tea (Camelia sinensis) extracts. Molecules 12, 423-432.

3. Ramirez-Mares MV, Chandra S \& de Mejia EG (2004) In vitro chemopreventive activity of Camellia sinensis, Ilex paraguariensis and Ardisia compressa tea extracts and selected polyphenols. Mutat Res 554, 53-65.

4. Filip R, Sebastian T, Ferraro G \& Anesini C (2007) Effect of Ilex extracts and isolated compounds on peroxidase secretion of rat submandibulary glands. Food Chem Toxicol 45, 649-655.

5. Gorzalczany S, Filip R \& Alonso MR (2001) Choleretic effect and intestinal propulsion of 'mate' (Ilex paraguariensis) and its substitutes or adulterants. J Ethnopharmacol 75, 291-294.

6. Baisch ALM, Johnston FL \& Stein P (1998) Endotheliumdependent vasorelaxing activity of aqueous extracts of Ilex paraguariensis on mesenteric arterial bed of rats. J Ethnopharmacol 60, 133-139.

7. Stein FLP, Schimidt B \& Furlong EB (2005) Vascular responses to extractable fractions of Ilex paraguariensis in rats fed standard and high-chloesterol diets. Biol Res Nurs 7, 146-156.

8. Lunceford N \& Gugliucci A (2005) Ilex paraguariensis extracts inhibit AGE formation more efficiently than green tea. Fitoterapia 76, 419-427.

9. Mosimann ALP, Wilhelm-Filho D \& Silva EL (2005) Aqueous extract of Ilex paraguariensis attenuates the progression of atherosclerosis in cholesterol-fed rabbits. BioFactors 23, 1-12.

10. Gugliucci A \& Stahl AJ (1995) Low density lipoprotein oxidation is inhibited by extracts of Ilex paraguariensis. Biochem Mol Biol Int 35, 47-56.

11. Campos AM, Escobar J \& Lissi EA (1996) The total reactive antioxidant potential (TRAP) and total antioxidant reactivity (TAR) of Ilex paraguariensis extracts and red wine. J Braz Chem Assoc 7, 43-49.
12. Gugliucci A (1996) Antioxidant effects of Ilex paraguariensis: induction of decreased oxidability of human LDL in vivo. Biochem Biophys Res Commun 224, 338-344.

13. Filip R, Lotito SB, Ferraco G \& Fraga CG (2000) Antioxidant activity of Ilex paraguariensis and related species. Nutr Res 20, 1437-1446.

14. Schinella GR, Troiani G, Davila V, de Buschiazzo PM \& Tournier HA (2000) Antioxidant effects of an aqueous extract of Ilex paraguariensis. Biochem Biophys Res Commun 269, 357-360.

15. Bracesco N, Dell M, Rocha A, Behtas S, Menini T, Gugliucci A \& Nunes E (2003) Antioxidant activity of a botanical extract preparation of Ilex paraguariensis: prevention of DNA double-strand breaks in Saccharomyces cerevisiae and human low-density lipoprotein oxidation. J Altern Complement Med 9, 379-387.

16. Chandra S \& De Mejia Gonzalez E (2004) Polyphenolic compounds, antioxidant capacity, and quinone reductase activity of an aqueous extract of Ardisia compressa in comparison to mate (Ilex paraguariensis) and green (Camellia sinensis) teas. J Agric Food Chem 52, 3583-3589.

17. Miranda DDC, Arçari DP, Pedrazzoli J Jr, Carvalho PO, Cerutti SM, Bastos DHM \& Ribeiro ML (2008) Protective effects of mate tea (Ilex paraguariensis) on $\mathrm{H}_{2} \mathrm{O}_{2}$-induced DNA damage and DNA repair in mice. Mutagenesis (Epublication ahead of print version 27 February 2008).

18. Lanzetti M, Bezerra FS, Romana-Souza B, Brando-Lima AC, Koatz VL, Porto LC \& Valenca SS (2008) Mate tea reduced acute lung inflammation in mice exposed to cigarette smoke. Nutrition 24, 375-381.

19. Kubo K, Saito M, Tadokoro T \& Maekawa A (1997) Changes in susceptibility of tissues to lipid peroxidation after ingestion on various levels of docosahexaenoic acid and vitamin E. $\mathrm{Br} J$ Nutr 78, 655-669.

20. Ohkawa H, Ohisshi N \& Yagi K (1979) Assay for lipid peroxides in animal tissues by thiobarbituric acid reaction. Anal Biochem 95, 351-358.

21. Lowry OH, Rosenbrough NJ, Farr AL \& Randall RJ (1951) Protein measurement with the folin phenol reagent. J Biol Chem 193, 265-275.

22. Folch J, Lees M \& Sloane Stanley GH (1957) A simple method for the isolation and purification of total lipides from animal tissues. J Biol Chem 226, 497-509.

23. Anonymous (1996) Physical and chemical characteristics of oils, fats and waxes, section I. In Official Methods and Recommended Practices of the American Oil Chemists' Society. Champaign, IL: AOCS Press.

24. Rathore N, John S, Kale M \& Bhatnagar D (1998) Lipid peroxidation and antioxidant enzymes in isoproterenol induced oxidative stress in rat tissues. Pharm Res 38, 297-302.

25. Araya J, Rodrigo R, Orellana M \& Rivera G (2001) Red wine raises plasma HDL and preserves long-chain polyunsaturated fatty acids in rat kidney and erythrocytes. Br J Nutr 86, $189-195$

26. Simonetti P, Cervato G, Brusamolino A, Gatti P, Pellegrini N \& Cestaro B (1996) Effect of red wine consumption on rat liver peroxidation. Alcohol 13, 41-45.

27. Soleas GJ, Diamandis EP \& Goldberg DM (1997) Wine as a biological fluid: history, production, and role in disease prevention. J Clin Lab Anal 11, 287-313.

28. Hrelia S, Bordoni A, Biagi PL, Galeotti T, Palombini G \& Masotti L (1994) The role $\Delta-6$ and $\Delta$-9-desaturase in the fatty acid metabolism of hepatomas with different growth rate. Biochem Mol Biol Int 34, 449-455.

29. Kuhlmann MK, Horsh E, Burkhardt G, Wagner M \& Kohler H (1998) Reduction of cysplatin toxicity in cultured renal tubular cells by the bioflavonoid quercetin. Arch Toxicol 72, 536-540. 
30. Bixby M, Spieler L, Menini T \& Gugliucci A (2005) Ilex paraguariensis extracts are potent inhibitors of nitrosative stress: a comparative study with green tea and wines using a protein nitration model and mammalian cell cytotoxicity. Life Sci 77, 345-358.

31. Paganga G, Miller N \& Rice-Evans C (1999) The polyphenolic content of fruit and vegetable and their antioxidant activities. What does a serving constitute? Free Rad Res 30, 153-162.
32. Carini U, Manusia F, Cresti PG \& Severi S (1998) Incidence of vasculogenic erectile dysfunction in multiple-region atherosclerosis pathology: diagnosis and therapeutic possibilities (article in Italian). Minerva Cardioangiol 46, 349-350.

33. Rodriguez SDV \& Hadley M (2002) Chrogenic acid modifies plasma and liver concentration of cholesterol, triacylglycerols, and minerals in (fa/fa) Zucker rats. J Nutr Biochem 13, 717-726. 